\title{
Rancang Bangun Aplikasi Mobile QR Code Untuk Validasi Pajak Reklame
}

\author{
A.A Ngr Narendra Dananjaya Ninggrat ${ }^{1}$, Ida Bagus Gede Manuaba ${ }^{2}$, Linawati ${ }^{3}$
}

[Submission: 28-02-21, Accepted: 06-03-2021]

\begin{abstract}
Advertisement is something media or equipment for delivering data, offering promotion, and presenting a product or service by using photos and interesting words, billboard tax recipients in the city of Denpasar have decreased every year even though the previous years the advertisement tax contributed the largest revenue in the city. The city of Denpasar, many who are not obedient in paying the advertisement tax, a breakthrough is needed to increase the return of advertisement tax revenue, where many tax users have not paid their obligations, the Denpasar city revenue agency has a duty to supervise the billboard tax in the city of Denpasar, so the design of mobile applications is created, Qr Code for billboard tax validation to oversee the billboard tax in the city of Denpasar, the system is designed to make it easier for Denpasar city revenue agency officers to validate the newly registered billboard tax because it is facilitated by the use of $Q R$ Code and it has been encrypted, use thealgorithm Speck so that security is guaranteed and in monitoring it has been integrated with google maps and using the djikstra method designed and created on the Android platform by utilizing web services.
\end{abstract}

Intisari- Reklame merupakan sesuatu media ataupun perlengkapan buat mengantarkan data,menawarkan mempromosikan,dan menghadirkan sesuatu produk ataupun jasa dengan memakai foto serta kata-kata yang menarik,Peneriman pajak reklame di Kota Denpasar tiap tahunya mengalami penurunan padahal tahun -tahun sebelumnya pajak reklame menyumbang pendapatan terbesar di Kota Denpasar, banyak yang tidak taat dalam pembayaran pajak reklame dibutuhkan sebuah terobosan untuk meningkatkan kembali pendapatan pajak reklame, dimana banyak dari penguna pajak yang belum membayarkan kewajibanya, badan pendapatan Kota Denpasar mempunyai tugas dalam pengawasan pajak reklame di Kota Denpasar maka tercipta rancang bangun aplikasi mobile Qr Code untuk validasi pajak reklame untuk mengawasi pajak reklame dikota denpasar, nya dirancang dapat memudahkan petugas badan pendapatan kota Denpasar dalam memvalidasi pajak reklame yang baru terdaftar karena dimudahkan dengan adanya pemanfaatan QR Code dan sudah terenkripsi mengunakan algoritma Speck jadi keamananya dijamin dan dalam pemantauanya sudah terintegrasi google maps dan mengunakan metode djikstra di rancang dan di buat dalam flatform android dengan

${ }^{I}$ Mahasiswa, Magister Teknik Elektro Universitas Udayana Gedung Pascasarjanan Universitas Udayana, Jl PB Sudirman Denpasar - Bali 8023 ( tlp 0361 - 555225; fax 0361 -4321 982; email : ngurah_narendra@student.unud.ac.id

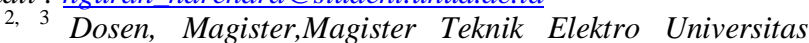
Udayana Gedung Pascasarjana. JL PB Sudirman Denpasar-Bali 8023 ( tlp: 0361-555225; fax: 0361-4321982; email; linawati@unud.ac.id),ibgmanuaba@unud.ac.id) pemanfaatan web service.

Kata Kunci- Reklame, Enkripsi, QR Code, Algoritma Djikstra.

\section{PENDAHULUAN}

Reklame adalah media periklanan besar, yang biasa ditempatkan pada zona secara universal, penafsiran Reklame merupakan sesuatu media ataupun perlengkapan buat mengantarkan data, menawarkan mempromosikan, dan menghadirkan sesuatu produk ataupun jasa dengan memakai foto serta kata-kata yang menarik. Pembuatan reklame bertujuan buat membagikan data kepada khalayak tentang sesuatu benda, jasa, ataupun perihal lain dengan metode yang menarik secara etimologis, kata" reklame" diadaptasi dari bahasa Spanyol, ialah" reclamos" yang maksudnya sesuatu seruan yang dicoba berulang- ulang dengan kata lain, makna reklame merupakan sesuatu aksi mengajak orang lain secara berulang- ulang buat melihat isi dari reklame tersebut [1].

Badan Pendapatan Daerah Kota Denpasar merupakan badan pelayanan yang mengendalikan sumber pemasukan serta penerimaan pajak, khususnya penempatan serta monitoring reklame yang terdapat diseluruh daerah Kota Denpasar, Peraturan Wali Kota Denpasar Nomor 2 Tahun 2011 kalau Pajak Reklame ialah sumber penghasilan wilayah yang berarti guna membiayai penerapan pemerintahan wilayah serta menaikkan pelayanan kepada publik[2].

Sehingga butuh pengaturan berlandaskan prinsip demokrasi, pemerataan serta keadilan, peranserta warga, serta akuntabilitas dengan mencermati kemampuan wilayah, reklame merupakan barang perlengkapan, perbuatan ataupun media yang wujud serta warna ragamnya di rancang buat tujuan komersial, pajak dari reklame meliputi reklame papan, reklame kain, reklame menempel sticker, reklame selebaran, reklame berjalan, reklame hawa, reklame apung, reklame suara, reklame film, reklame peragaan,Subjek pajak reklame merupakan orang individu ataupun yang bisa dikenakan pajak reklame, dasar dari pengenaan pajak reklame tarif pajak diresmikan $25 \%$ yang berikutnya jadi( PAD) Pemasukan Asli Daerah Serta metode penagihan dari pajak reklame tersebut walikota memastikan bertepatan pada jatuh tempo pembayaran serta penyetoran pajak yang terutang sangat lama 30 ( Tiga Puluh) hari kerja sehabis dikala terutangnya pajak[2].

Dari informasi yang penulis miliki pada laporan realisasi pemasukan kota Denpasar tahun anggaran 2018, pajak reklame menyumbang realisasinya $114,18 \%$ dari targetnya 1,5 Milyar sudah melebihi targetnya. sebaliknya pada Bulan juli Tahun 2019 menyusut jadi $63,77 \%$ realisasinya yang di mana banyak dari para penguna pajak yang belum membayarkan 
kewajibanya yang dimana perdampak signifikan terhadap PAD kota Denpasar.

Perlunya merancang system yang dapat memudahkan petugas Badan Pendapatan Kota Denpasar memudahkan dalam pemantauan pajak reklame di Kota Denpasar bertujuan untuk memberikan data kepada petugas Badan Pendapatan Kota Denpasar untuk mengecek reklame yang hendak di validasi, serta dimana saja tepatnya dipasangi Reklame Billboard tersebut, Nantinya system yang di buat mengunakan teknologi $Q r$ Code untuk memvalidasi reklame dalam pengamanan $Q r$ Code mengunakan Algoritma Speck, agar informasi pada reklame dan data - data yang tertuang pada $Q r$ Code aman, sebab informasi yang terdapat pada $Q r$ Code sangat penting untuk Badan Pendapatan kota Denpasar, Algoritma Djikstra digunakan dalam penetuan jarak serta sebaran antar reklame serta titik dimana reklame itu berada.

\section{LITERATUR REVIEW}

\section{A. Reklame}

Reklame yakni salah satu sarana dalam mempresentasikan suatu pesan berupa barang maupun jasa, Reklame berasal dari bahasa Spanyol, kata $R E$ yang artinya kembali maupun berulang- ulang dan CLOMOS yang artinya berseru, reklame yakni masing- masing pernyataan yang secara sadar ditujukan kepada publik dalam bentuk apapun pula yang dicoba oleh seorang partisipan setelah itu lintas perdagangan, yang diarahkan kearah sasaran penjualan sebagian benda maupun jasa yang dimasukkan, oleh pihak yang berkepentingan dalam perdaganganm [1].

\section{B. Enkripsi}

Enkripsi proses atau mekanisme untuk mengubah sebuahpesan dari yang dapat dimengerti menjadi pesan yang tidak dapat dimengerti dengan sebuah kode/metode tertentu $(1,3,4)$, Dengan adanya enkripsi suatu data akan diacak dengan sebuah kunci enkripsi untuk menjadi susunan karakter yang tidak bermakna bagi seseorang yang tidak memiliki kunci untuk proses dekripsinya[3].

\section{Qr Code}

$Q R$ Code adalah suatu jenis kode matriks atau kode batang dua dimensi yang dikembangkan oleh Denso Wave, sebuah divisi Denso Corporation yang merupakan sebuah perusahaan Jepang dan dipublikasikan pada tahun 1994 [4]. QR Code mampu menyimpan informasi secara horizontal dan vertikal, oleh karena itu secara otomatis $Q R$ Code dapat menampung informasi yang lebih banyak,daripada kode batang $Q R$ Code mampu menyimpan semua jenis data, seperti data angka/ numerik, alphanumerik, biner, kanji/ kana. Selain itu $Q R$ Code memiliki tampilan yang lebih kecil daripada barcode [5]Titiktitik dalam $Q R$ Code mengandung Format dan informasi versi serta konten itu sendiri QR Codejuga mencakup koreksi kesalahan tingkat tertentu,yang didefinisikan sebagai L, M, Q, atau H. Sejumlah koreksi kesalahan rendah (L) memungkinkan QR Code mengandung lebih banyak konten[6]. $Q R$ Code bekerja dengan cara menerjemahkan gambar $Q R$ Code menjadi suatu data atau tindakan yang dapat dilakukan oleh perangkat yang memindai[7]. Terdiri dari finder patterns, alignment patterns, timing patterns, dan quiet zone [8]

\section{Algoritma Speck}

Diusulkan secara terbuka pada bulan Juni 2013 oleh sekelompok peneliti di Direktorat Riset Keamanan Nasional AS. Karya desain dimulai pada tahun 2011, dan jumlah kriptanalisis yang signifikan telah dilakukan (tidak hanya oleh para desainer, namun oleh banyak orang di seluruh perusahaan) pada saat menjelang publikasi. Banyak cipher blok ringan telah diusulkan, dan banyak tampil dengan baik di berbagai platform terbatas. SPECK masing-masing memiliki beberapa instantiasi, yang mendukung ukuran blok 32, 48, 64, 96, dan 128 bit, dan dengan tiga ukuran kunci yang berbeda [9].

\section{E. Algoritma Djikstra}

Algoritma Dijkstra merupakan algoritma yang digunakan untuk menentukan jarak terpendek dari satu vertex ke vertex yang lainnya pada suatu graph berbobot,jarak antar vertex adalah nilai bobot dari setiap edge pada graph.[10].diberi nama sesuai nama penemunya,Edsger Wybe Dijkstra. Algoritma Dijkstra mencari lintasan terpendek dalam sejumlah langkah. Algoritma ini menggunakan prinsip Greedy yang menyatakan bahwa pada setiap langkah kita memilih sisi yang berbobot minimum dan memasukkannya ke dalam himpunan solusi[11].

\section{F. Android}

Android adalah sebuah operasi untuk perangkat mobile berbasis Linux yang mencakup operasi, middleware dan aplikasi Android menyediakan platform terbuka bagi para pengembang untuk menciptakan aplikasi mereka [12]. Sebagian besar inti Android dirilis di bawah lisensi open source Apache tetapi sejumlah besar perangkat lunak aktif Android seperti seperti Play Store, Google Search, Layanan Google Play, Google Music, dan sebagainya adalah hak milik dan berlisensi. android saat ini merupakan operasi mobile yang paling banyak digunakan[13].

\section{G. Website}

Website dapat diartikan sebagai serangkaian halaman halaman yang bisa menampilkan informasi berbentuktulisan, gambar, suara atau gabungan dari semuanya[14]. Meliputi nformasi teks, gambar diam atau gerak, animasi, suara, dan atau gabungan dari semuanya, baik yang bersifat statis maupun dinamis yang membentuk satu rangkaian bangunan yang saling terkait, yang masing- masing dihubungkan dengan jaringan-jaringan halaman [15].

\section{H. Android Web View}

Android WebView adalah komponen untuk operasi (OS), Android yang memungkinkan aplikasi Android untuk menampilkan konten dari web langsung kedalam suatu aplikasi [16].

\section{Web Gis}

WebGIS merupakan sebuah proses merancang, mengimplementasikan dan mengirim data layanan geospasial menggunakan teknologi World Wide Web yang biasanya 
sering disebut Website[17]. Web GIS ( Google Information System ) juga merupakan Distributed System yang berbasis web sehingga pengguna dapat menggunakan GIS melalu web[18].

\section{J. Pengujian Black Box}

Pengujian dilakukan untuk mengetahui tingkat akurasi dan ketepatan informasi yang dihasilkan. Sehingga sesuai dengan kebutuhan pengguna yang diharapkan. Hal ini bertujuan untuk mengevaluasi kelayakan evaluasi aplikasi yang dibangun [19].

Metode Blackbox Testing adalah sebuah metode yang dipakai untuk menguji sebuah software tanpa harus memperhatikan detail software Pengujian ini hanya memeriksa nilai keluaran berdasarkan nilai masukan masing masing. Tidak ada upaya untuk mengetahui kode program apa yang output pakai Proses Black Box Testing dengan cara mencoba program yang telah dibuat dengan mencoba memasukkan data pada setiap formnya[20].

\section{METODELOGI PENELITIAN}

\section{A. Alur Penelitian}

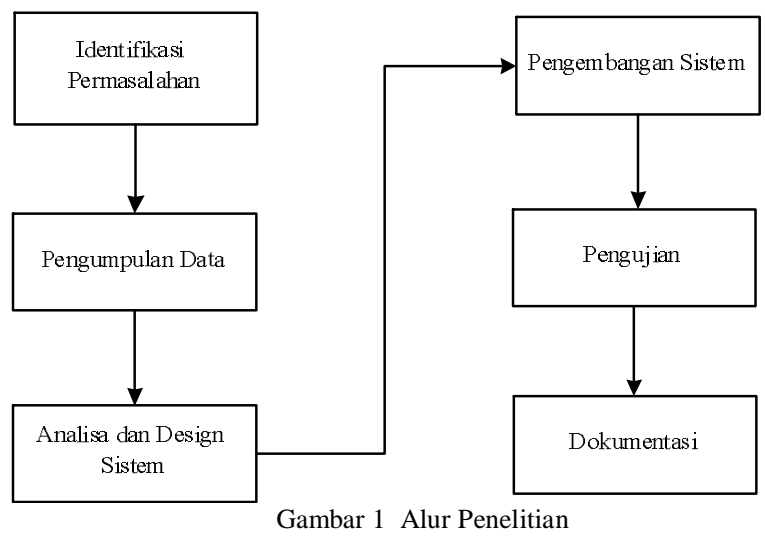

\section{Identifikasi Permasalah}

Melakukan identifikasi permasalah yang terjadi pada badan pendapatan kota Denpasar khusunya pada pajak reklame yang mengalami penurunan.

\section{Pengumpulan Data}

Proses pencarian dan pengumpulan data atau informasi yang dibutuhkan seperti data pada Studi Pustaka tentang peraturan dan masalah yang terjadi atau mencari di internet berupa penelitian yang pernah dilakukan atau yang mendekati tentang pajak reklame yang nantinya bisa menjadi bahan referensi atau acuan untuk dilakukan penelitian dan menangulangi masalah Pajak reklame

\section{Analisa dan Desain}

Analisa dan desain dilakukan untuk merancang dan mengolah data-data yang diperlukan agar menjadi sebuah informasi setelah itu di rancang dibuatkan prototype seperti apa system yang di buat nantinya serta melakukan analisa terhadap metode yang digunakan dalam Pengembangan
Rancang Bangun Aplikasi Mobile $Q r$ Code Untuk Validasi Pajak Reklame.

\section{Pengembangan}

Dari hasil analisa dan design tersebut dilakukan proses pengembangan sebagai interface atau tampilan dari Rancang Bangun Aplikasi Mobile Qr Code Untuk Validasi Pajak Reklame.

\section{Pengujian}

Selanjutnya yang dibangun dilakukan pengujian untuk mengetahui seberapa besar tingkat keberhasilan dari Rancang Bangun Aplikasi Mobile Qr Code Untuk Validasi Pajak Reklame Pengujian dilakukan dengan mencari tingkat keberhasil seberapa efektif nya pemanfaatan $Q r$ Code dalam Validasi Pendapatan Pajak Reklame dan juga penulis untuk mengetahui bahwa program dijalankan sesuai dengan apa yang dibutuhkan oleh Badan Pendapatan Kota Denpasar, Pengujian dilakukan dengan metode Black Box.

\section{Dokumentasi}

Proses dokumentasi merupakan proses dalam pembuatan laporan yang berisi informasi tentang proses, hasil dan hal yang berkaitan tentang penelitian.

\section{B. Gambaran Umum}

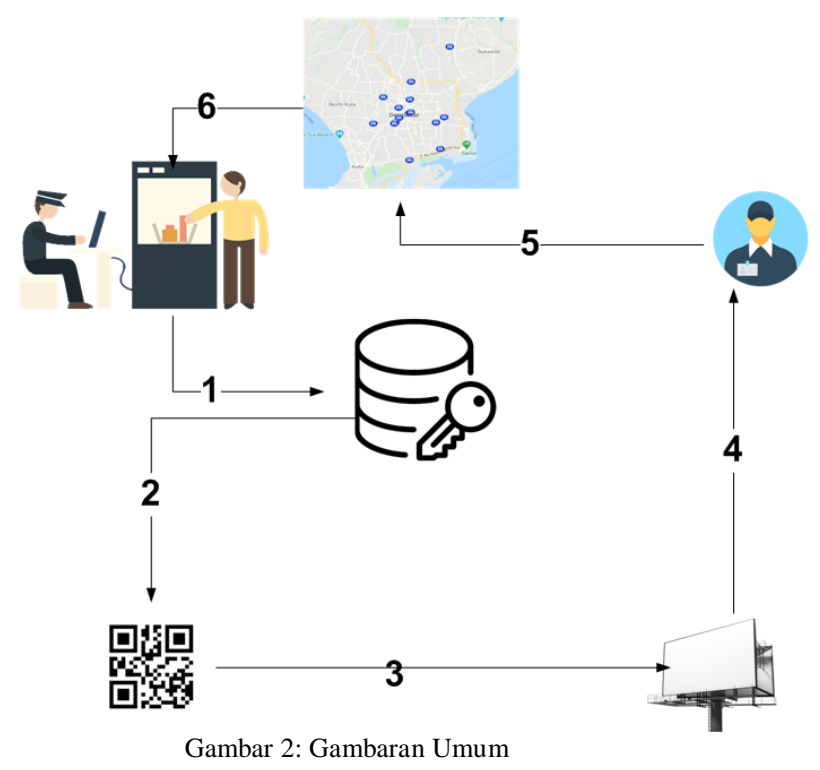

Peran - peran tiap elemen dalam gambaran system di beri petunjuk dengan angka :

1. Melakukan pengajuan pemasangan reklame

2. Data pada papan iklan akan memasuki jenis faktor dasar data, bahan yang digunakan, lokasi lokasi, waktu, periode waktu dan ukuran media billboard.

3. memberikan $Q r$ Code yang sudah terenkripsi, dan plaintextnya

p-ISSN:1693 - 2951; e-ISSN: 2503-2372

A.A Ngr Narendra Dananjaya Ninggrat Rancang Bangun Aplikasi Mobile 
4. Petugas Melakukan Pengecekan kelapangan dengan $Q r$ Code yang sudah di berikan Melakukan deskripsi dan validasi reklame.

5. Output berupa keaslian lokasi peta sebaranya dan di lihat jarak terdekat pemasangan tiap reklame dan masa waktu dari reklame tersebut.

6. System sudah di validasi dan admin dapat melihat sebaran reklame di kota Denpasar.

\section{Use Case Diagram}

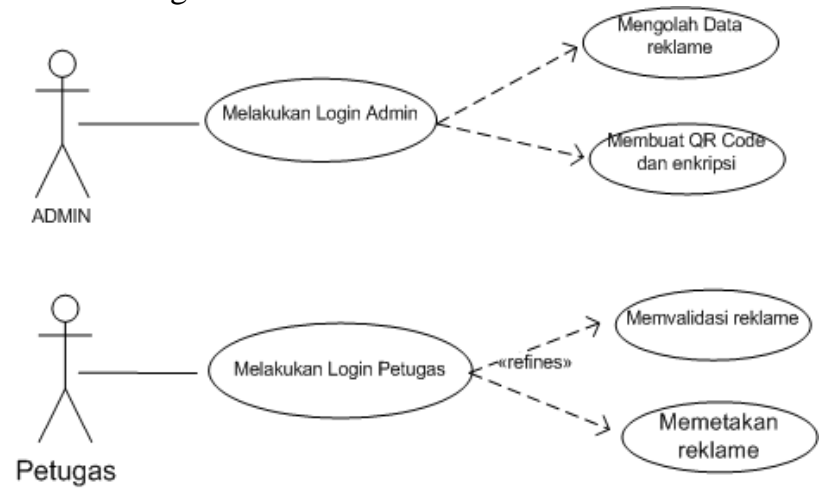

Gambar 3 Diagram Use Case

Use case diagram menggambarkan fungsionalitas yang diharapkan dari sebuah yang menjelaskan keseluruhan kerja secara garis besar dengan mempresentasikan interaksi antara pengguna yang dibuat, serta memberikan gambaran fungsifungsi pada tersebut. Berikut ini adalah gambar dari use case diagram dari Rancang Bangun Aplikasi Mobile Qr Code Untuk Validasi Pajak Reklame, memiliki 6 use case yaitu melakukan login admin, mengolah data reklame, membuat $Q r$ Code dan enkripsi, melakukan login petugas, memvalidasi reklame, memetakan reklame

\section{Pengujian}

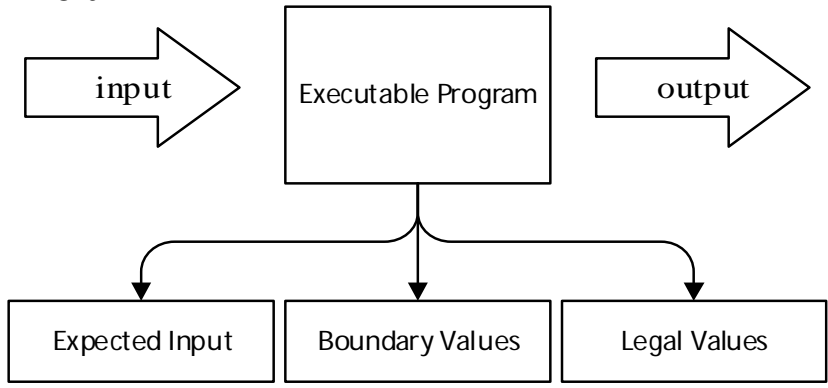

Gambar 3 Pengujian

Tahapan pengujian ini berguna untuk mengetahui apakah sudah berjalan sesuai dengan tujuan atau tidak. Di samping itu, pengujian juga dilakukan dengan tujuan untuk mengetahui kekurangan dari ini baik berupa error atau kekurangan lainnya point - point berupa data inputan pada program yang dinilai apakah sudah sesuai dengan keluaran yang di inginkan, mulai dari ada masalah atau tidak dan nilai keluaran dari hasil output disesuaikan dengan hasil input yang di inginkan yang dilakukan pengujian.

\section{HASIL DAN PEMBAHASAN}

E. Data Reklame menjadi Qr Code

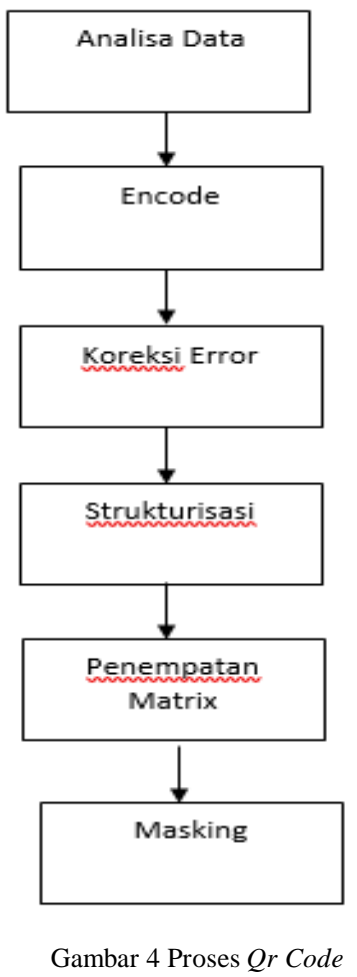

Pada gambar $4 \mathrm{~d}$ bagaimana proses pembentukan Qr Code yang dibuat pada penelitian ini.

- Data Analysis : data ID pada reklame tadi menjadi patokan dasar .

- Data Encodation : masuk ke data encodation dimana di rubah menjadi position aligment pada Qr Code berbentuk matrix.

- Error Correcting Coding :akan di convert apakah terjadi erro apa tidak .

- Structure Final Message : di bentuk lah code beberapa matrix dalam bentuk timing.

- Module Placement in Matrix : module Qr Code sudah berbentuk matrix.

- Masking : pembentukan dalam bentuk format JPG .

- Format and Version Information : disesuaikan dengan format dan versi yang digunakan .

F. Proses Enkripsi dan Dekripsi Algoritma Speck 


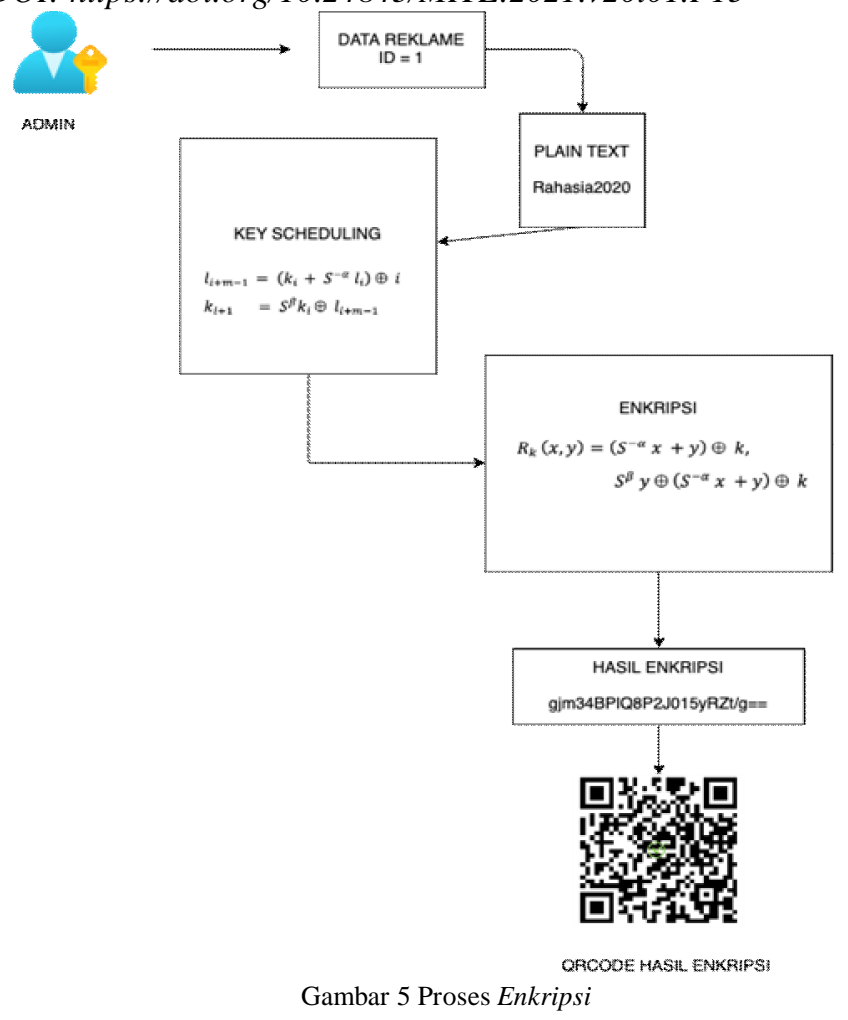

Admin melakukan input data reklame, di contohkan pada gambar diatas id dari reklame adalah "1", dari angka 1 tersebut akan dilakukan enkripsi dengan menggunakan algoritma speck.

Plain text dari enkripsi adalah "Rahasia2020". Proses pertama algoritma aspeck adalah key scheduling, Alur kerja dari proses pemrograman utama adalah sebagai berikut:

1. Dalam $l 0$, ia mengalami perubahan melingkar pada 8 kali.

2. Hasil perubahan di penambahan modul ki.

3. Hasil penambahan modul di XOR Kandengan I dan disimpan di TMP.

4. Di ki melanjutkan ganti bola melingkar 3 kali di sebelah kiri.

5. Hasil perubahan dalam XOR adalah TMP.

6. Dibuat dengan beberapa putaran yang telah dibuat sesuai dengan jenis SPECK yang digunakan

Setelah proses key scheduling hasil dari key scheduling akan di bawa ke proses enkripsi, dimana proses enkripsi memiliki tahapan sebagai berikut :

1. Dalam $X 0$ pengalaman perubahan melingkar pada 8 kali.

2. Hasil perubahan dalam modul penambahan dengan $X 1$.

3. Hasil penambahan modul dalam XOR kanan dengan $k i$ dan menghasilkan nilai $X 0$.

4. Dalam $X 1$ mengalami perubahan melingkar 3 kali di sebelah kiri.

5. Hasil perubahan XOR benar dengan $X 0$.

6. Lakukan dengan serangkaian putaran yang telah ditetapkan sesuai dengan jenis SPECK yang digunakan.

Dengan proses enkripsi hasil yang didapat adalah sebagai berikut :
Hasil Enkripsi :gjm34BPIQ8P2J015yRZt/g==

ID reklame : 1

Plain Text : Rahasia2020

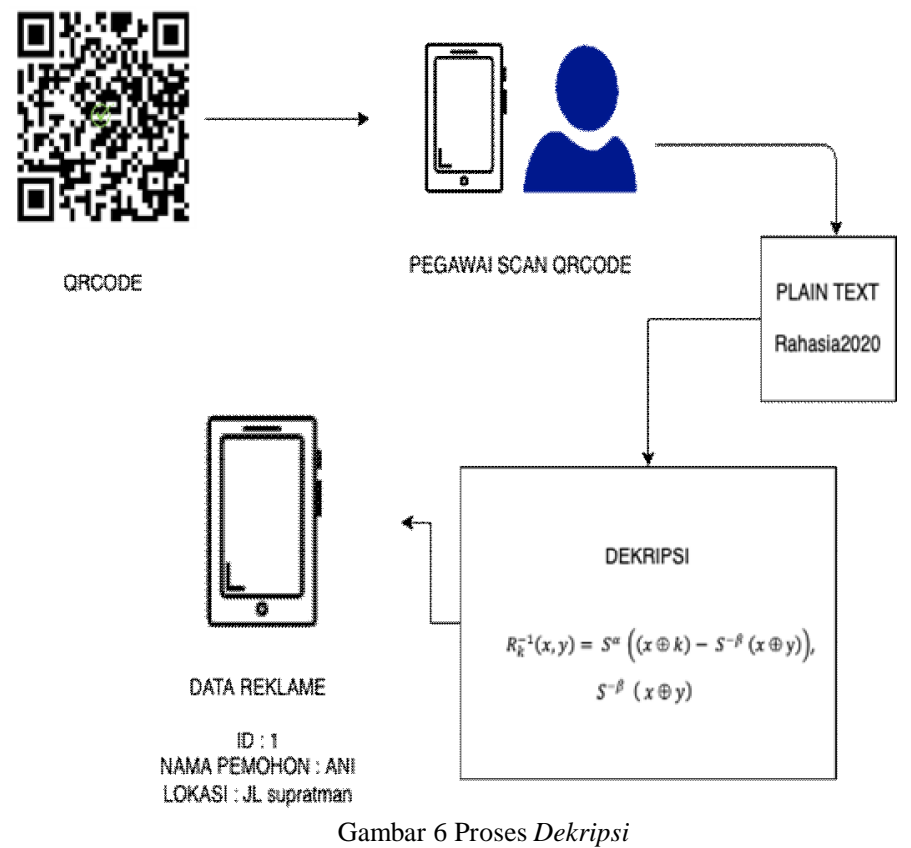

Tahap dekripsi pada ini yang pertama adalah pegawai atau petugas melakukan scan pada masing - masing smartphone ke QRCode yang tertera pada reklame.

Setelah melaukan scan pegawai / petugas akan diminta untuk input plain text dari enkripsi yaitu "Rahasia2020", selanjutnya proses dekripsi akan berjalan dengan tahapan sebagai berikut :

1. Y0 di xor tepat dengan $k T-i-l$.

2. Hasil XOR dilakukan oleh keepe melingkar kiri hingga 8 kali.

3. Hasil perubahan dalam pengurangan modul con $Y 1$ dan menghasilkan nilai $Y 0$.

4. $Y 0$ di xor kanan dengan $Y 1$.

5. Hasil XOR dilakukan di sebelah kanan melingkar 3 kali dan menghasilkan nilai $Y 1$.

6. Dibuat dengan beberapa putaran yang telah dibuat sesuai dengan jenis bintik yang digunakan.Jika plain text yang dimasukan benar maka data reklame akan tampil sesuai ID yang telah di scan oleh pegawai / petugas.

G. Implementasi Algoritma Djikstra Pada GIS

Algoritma Dijkstra menghitung berat terkecil dari satu simpul ke simpul lainnya, Dengan makna lain, Dijkstra menghitung karir berdasarkan jarak terpendek melakukan semua alamat alamat. Komponen Algoritma Dijkstra adalah grafik dan matriks kettangan, Graf adalah sesama $\mathrm{g}=(\mathrm{v} . \mathrm{e})$. Geometri Grafed digambarkan sebagai kelompok node dalam bidang Dwimatra (Bidimensional) yang terkait dengan serangkaian garis (sisi). 

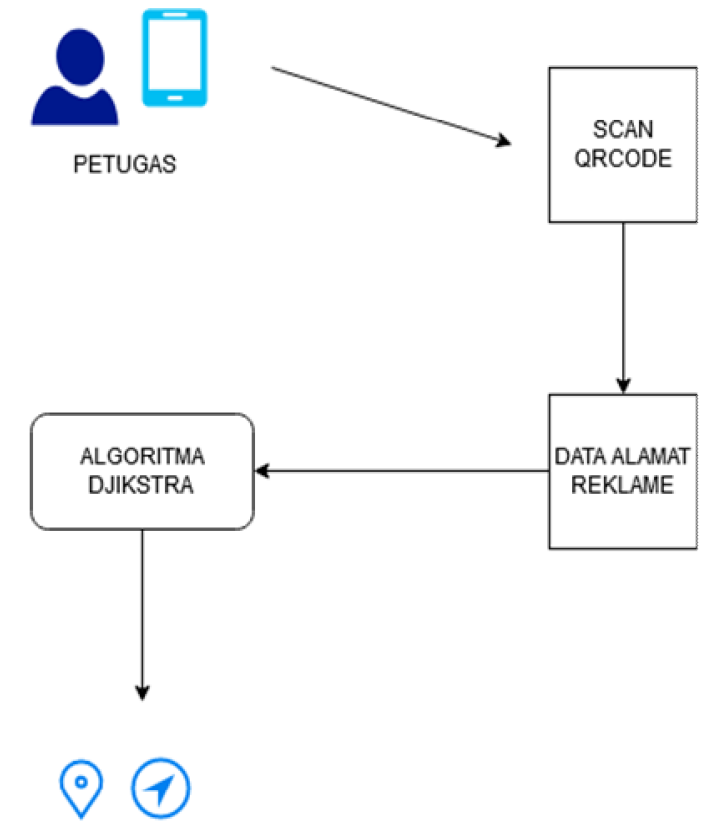

LOKASI IKLAN TERDEKAT

Gambar 7 Proses Djikstra

Dalam matriks partai ada komponen penting, karena kompiler adalah lintasan, Dua knot dalam graffdin adalah tetangga jika mereka terhubung langsung langsung di satu sisi, Panjang panjang awal volt awal ke node vn dalam grafik intermiten antara node dan sisi, dalam implementasinya dalam ini, setiap node di lokasi titik peta dihitung dan berat titik dihitung ke yang lainnya, Ketika petugas berada pada titik tertentu, akan mencari bobot terendah dari titik asal ke lokasi peta di sekitar petugas.

H. Design Interface

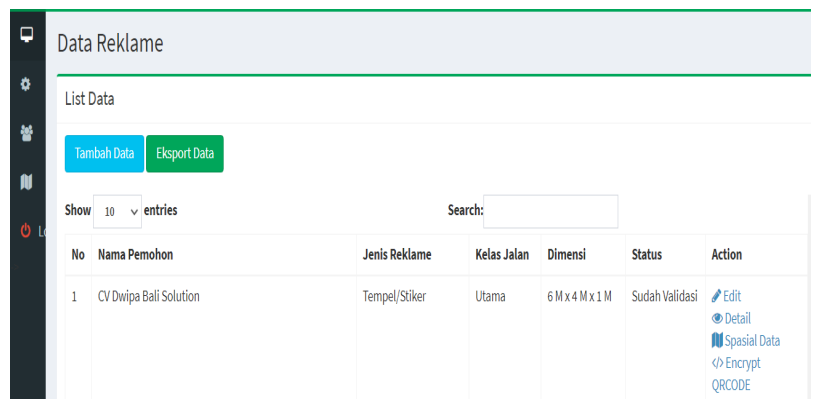

Gambar 8 Data Reklame

Tampilan data reklame pada yang di mana data inputanya berupa data reklame yaitu : Nama Pemohon, alamat pemohon, no telpon pemohon, jenis reklame, alamat pemasangan, Kecamatan, Kelurahan, Kelas Jalan pada reklame, Nama Perusahaan, Tanggal Berakhir, terdapat juga tampilan detail pada reklame yang sudah terinput tadik.

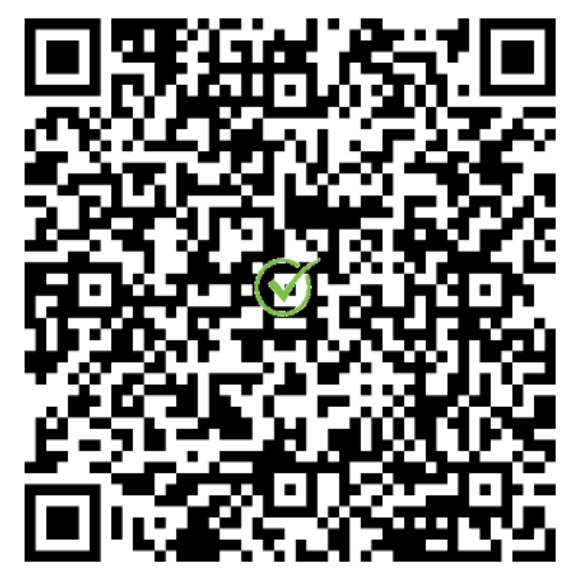

Hasil Enkripsi : https://snow.co.id gis_reklame petugas cek.php?id=gjm34BPIQ8P2J015yRZtg==
ID reklame : 1
Penempatan Itlan : J. Teuku Umar Barat No. 99, Desa Pemecutan Klod, Denpasar Barat
Plain Text : Rahasia2020
Gambar 9 Qr Code Hasil Enkripsi

Dan ini adalah tampilan $Q r$ Code yang datanya sudah terenkripsi, dimana di tunjukan juga bentuk dari hasil enkripsi sebelum dijadikan $Q r$ Code, ID reklamenya, penempatan Iklanya dan Plain Text yang digunakan pada proses Enkripsi seperti apa.

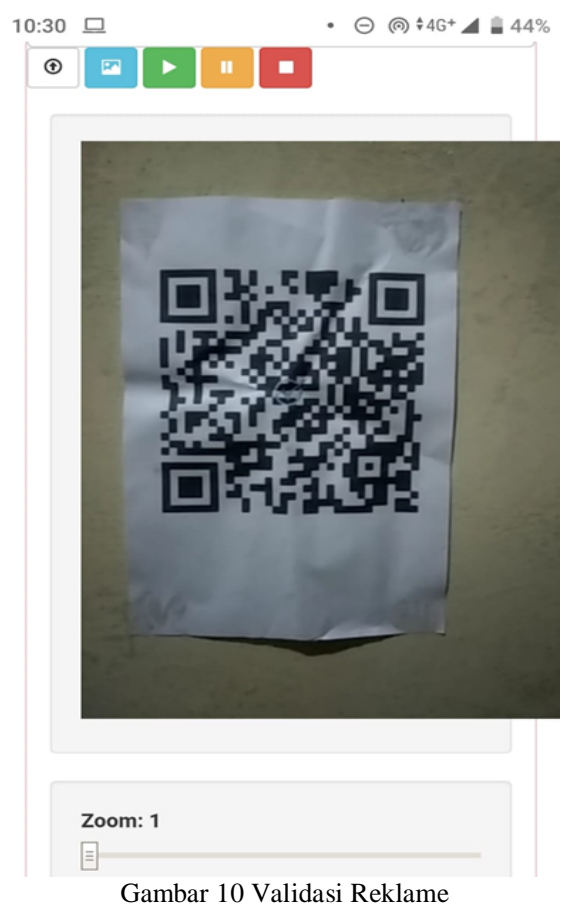

Tampilan dari admin petugas pada Validasi reklame, di lapangan untuk validasinya mengunakan fungsi pada camera handphone yang dimana petugas akan mengarahkan kameranya untuk menscan $Q r$ Code yang sudah enkripsi yang nantinya akan muncul hasil keluaran data yang sudah di dekripsi 


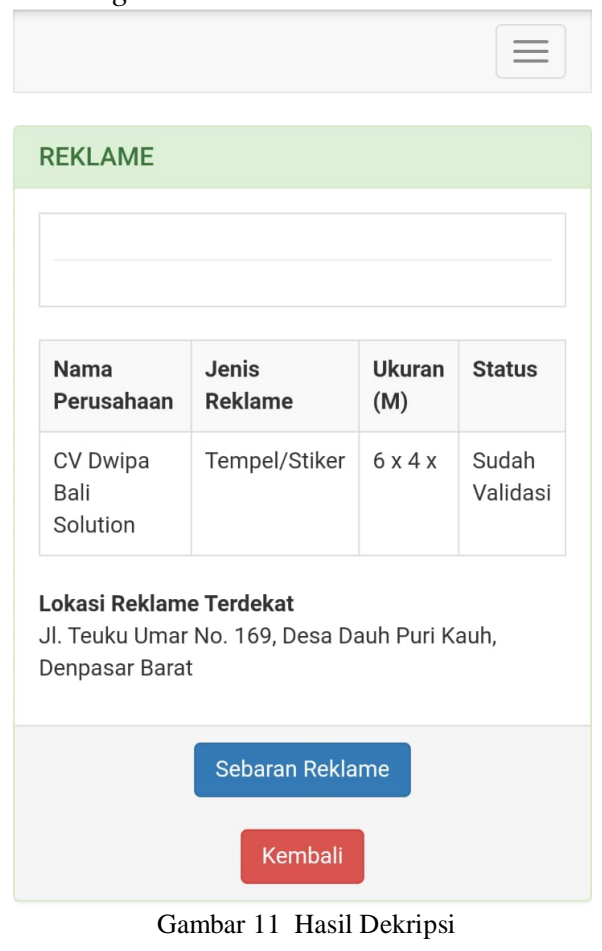

Tampilan dari hasil dekripsi yang dimana sudah tertera informasi Nama perusahaan reklame tersebut ukuran, dan statusnya berhasil di validasi oleh petugas dan juga terlihat di mana lokasi reklame terdekat yang baru saja di validasi sehinga memudahkan petugas di lapangan mengetahui di mana saja sebaran reklame tersebut.

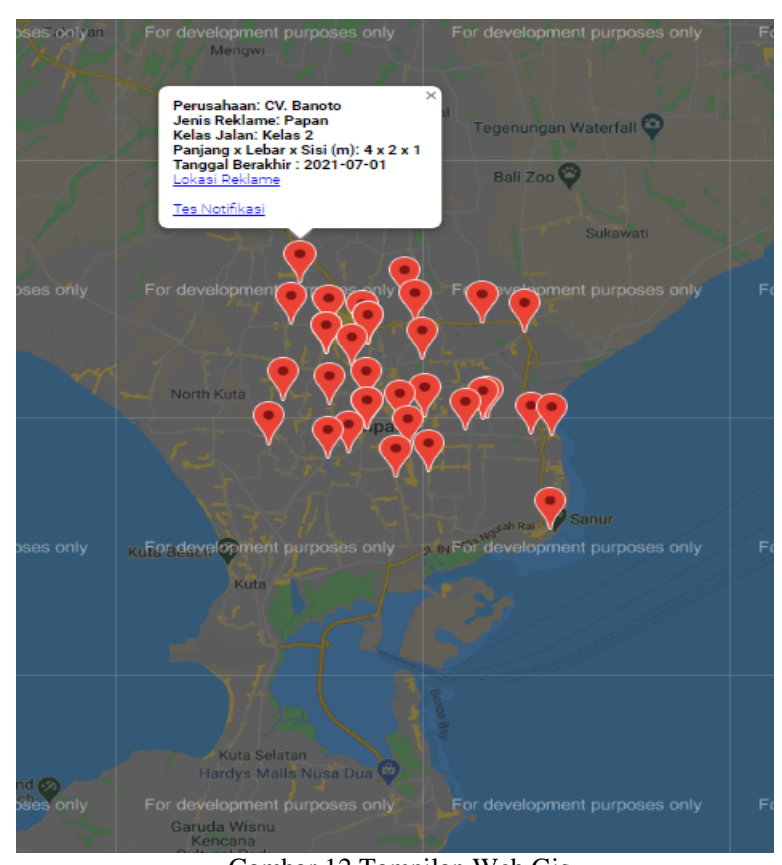

Gambar 12 Tampilan Web Gis

Tampilan GIS dari data reklame yang sudah di pasang di kota Denpasar dimana di tampilkan data,

A.A Ngr Narendra Dananjaya Ninggrat Rancang Bangun Aplikasi Mobile tersebut sudah di validasi muncul nzmz perusahaan dari reklame tersebut, jenis reklame tersebut dan reklame tersebut terletak pada jalan apa,

\section{KESIMPULAN}

Berdasarkan pembahasan dari hasil yang di capai pada Rancang Bangun Aplikasi Mobile Qr Code Untuk Validasi Pajak Reklame :

1. Merancang aplikasi mobile $Q r$ Code untuk validasi pajak Reklame dalam pengawasan pajak reklame di Kota Denpasar.

2. Sisem ini di rancang dan digunakan petugas Badan Pendapatan Kota Denpasar dalam memvalidasi pajak reklame yang baru terdaftar karena dimudahkan dengan adanya pemanfaatan $Q R$ Code dan sudah dienkripsi mengunakan Algoritma Speck jadi keamananya dijamin dan dalam pemantauanya sudah terintegrasi google maps mengunakan metode Djikstra dalam penentuan jarak Reklame dan titik dimana antar Reklame di Kota Denpasar.

3. ini dibuat dalam Flatform Android dengan pemanfaatan Android Web View dan pemetaanya mengunakan Web GIS

\section{REFERENSI}

[1] Dyah Widyaningrum, B. S. L. N., 2017. Analisis Sebaran Reklame Bilboard Terhadap Lokasi dan Nilai Pajak Reklame Berbasis Informasi Geografis. Jurnal Geodesi Undip, Volume 6, pp.

[2] Bapenda, 2011. Peraturan Daerah Kota Denpasar Nomor 2 tahun 2011. [Online]Availableat:

https://pendapatan.denpasarkota.go.id/uploads/download/download 19 0907080751_PERDANO2TAHUN2011TENTANGPAJAKREKLAM

E.pdf [Accessed Selasa Oktober 2020]..

[3] Maricar, M. A. \& Sastra, N. P., 2018. Efektivitas Pesan Teks dengan Chiper Substitusi, Vigenere Chiper, dan Chiper Transposisi. Majalah Ilmiah Teknologi Elektro, Volume 12, p. 1

[4] Aldhi Kurniawan, D. W. U., 2018. Qr Code Mobile sebagai pendukung rekam medilk berkas rawat jalan RS. St. Elisabeth Semarang. Jurnal Informatika, Volume 3, p. 1.

[5] Wibowo, G. P. \& Purwantoro, H., 2020. Perancangan Informas Pemesanan Tiket Bus Damri Di Bandara XYZ Mengunakan Qr Code dan Web Base. Jurnal Informasi, Volume 7, p. 2.

[6] Ardana, S. B., H. \& Taufik, M., 2019. Rancang Bangun Pembelian Menggunakan Pemindaian Qr Code di Inception 99 Store Berbasis Android. JARTEL ISSN, Volume 8, p. 1

[7] Paramartha, I. G. N. D. \& Surananta, I. W. A., 2020. Analisis Perancangan Absensi Dengan Mengunakan Qr Code dan Metode Byod. Jurnal Teknologi Informasi dan Komputer, Volume 6, p. 2.

[8] Setiadi, M. D. \& Rosmawarni, N., 2020. Perancangan Aplikasi Qr Code Sebagai Media Informasi Pengenalan Satwa Kebun Binatang Berbasis Website. Jurnal Rekayasa Informasi, Volume 9, p. 1.

[9] Yuniar Siska Fatmala, A. K. M. D., 2018. Implementasi Algoritma Speck untuk Enkripsi dan Dekripsi pada Qr Code. Jurnal Pengembangan Teknologi Informasi dan Ilmu Komputer, Volume 2, p.

[10] Muhammad Khoirudin harahap, N. K., 2017. Pencarian Jalu Terpendek dengan Algoritma Djikstra. SInkron, Volume 2, p. 2.

[11] Arabigh, M. H. \& Saurina, N., 2020. Pencarian Toko Batik di wilayah Surabaya Dengan Algoritma Djikstra. Information Technology Journal, Volume 6, pp. 47-54M. s. k. Dwi sunaryono, "Rancang Bangun Perangkat lunak untuk monitoring harga produk semen indonesia dan kinerja area manager pada perangkat bergerak dengan teknologi qr code," -, vol. 0, p. 2, 2016.

[12] Wahyuni, T., sopiandi \& Raharjo, S., 2020. Informasi Geografis Wisata Kuliner Berbasis Android. Infotech Jurnal, Volume 6, p. 2 ..

[13] Putra, P. W., Sudarma, M. \& Pramaita , N., 2019. Rancang Bangun Enkripsi dan Deskripsi SMS Mengunakan AES dan Blowfish Cipher 
serta Kombinasinya Pada telepon seluler berbasis Android. Majalah Ilmiah Teknologi Elektro, Volume 18, p. $1 .$.

[14] Putra, I. K. C. A., Saputra, K. O. \& Ariastina, W. G., 2019. Evaluasi Kualitas dan Kepuasan Pengguna Website Imissu dengan Penerapan Metode Webqual 4.0. Majalah Ilmiah Teknologi Elektro, Volume 18, p. 2 .

[15] Wijaya, P. A. K., Wiharta, D. M. \& Sastra, N. P., 2019. Perencanaan Strategis Menuju Webometrics dan 4ICU Pada Website Perguruan Tinggi. Majalah Ilmiah Teknologi Elektro, Volume 18, p. $1 .$.

[16] Fietri Setiawan Sulaiman, 2019. Aplikasi Penjadwalan dan Booking Online Mengunakan Teknologi Android Webview. Media Journal Informatika, 11(-), p. 2.

[17] Rukmana, M. Y. \& Ramadhani , F., 2018. Implementasi Algoritma Djikstra pad Webgis untuk Pencarian Lokasi SPBU di Kota Malang. Jurnal Pengembangan Teknologi Informasi dan Ilmu Komputer, Volume 2, p. 6.

[18] Durand, G. M., Tooy , D. \& Pakasi, S., 2020. Rancang Bangun Informasi Industri Kelapa di Provinsi Sulawesi Utara Berbasis WEB GIS. E journal Unsrat, Volume 2, p. 1..

[19] Anam, K. \& Hartono, O. D., 2019. Aplikasi Pemandu Pencarian Wisata Terdekat Berbasis GIS Android Dengan Algoritma Djikstra. JSakti, Volume 3, p. 1.

[20] Fadli Cahya Ningrum, D. S., 2019. Pengujian Blackbox pada Aplikasi Seleksi Sales Terbaik Mengunakan Teknik Equivalence Partitions. Jurnal Informatika Universitas Pamulang, Volume 4, p. 4. 